\title{
Greenhouse Experimental Methods Towards in-situ Burial and Restoration of Contaminated Sites in Submerged Wetlands
}

\author{
Alice Benzecry \\ Fairleigh Dickinson University, School of Natural Sciences, 1000 River Road Teaneck, New Jersey, 07666, USA
}

\begin{abstract}
As a result of commercial and industrial activities conducted in the absence of environmental regulations and enforcement in the past, sediments contaminated by organic compounds, heavy metals, and other potentially toxic chemicals have accumulated in many of the world's deepwater and wetland environments. These sediment-borne contaminants can eventually become incorporated into aquatic food webs and adversely affect ecological receptors like benthic organisms and fish, and ultimately pose a risk to human health. This laboratory research tested a commercial product AquaBlok $^{\mathrm{TM}}$ (patented, composite-aggregate technology comprised of a solid core, an outer layer of clay material, and polymers) as an in-situ capping technology that could be used to remediate and/or manage contaminated sediments in the New Jersey Hackensack Meadowlands, a superfund site. In a greenhouse setting, tubs containing representative Meadowland marsh soil and water were capped with AquaBlok. This research not only examined the potential use of this product as an in-situ capping material and possible substrate for flora colonization, but also examined the imp rovements of the same patented, clay mineral-based composite aggregate technology (SubmerSeed ${ }^{\mathrm{TM}}$ ) as an alternative to traditional means of wetland plant propagation. At the end of a two-year period, both the sediment/cap and vegetation plant tissues were examined for metallic contaminants (including $\mathrm{Cd}, \mathrm{Cr}, \mathrm{Cu}, \mathrm{Pb}, \mathrm{Hg}$, and $\mathrm{Zn}$ ). Overall, capping provided a less contaminated substrate. Results indicated that AquaBlok cap alone did not allow contaminants in the sediment below to breakthrough. Nevertheless, vegetation colonization was restricted to a limited number of plant species. Furthermore, plants growing in AquaBlok were less robust with lower dry weight and smaller root system than plants growing in uncapped sediments despite the fact that their tissue contained smaller amounts of metallic contaminants. The improvements of the clay mineral-based composite aggregate technology (SubmerSeeds) as an alternative to traditional means of plant propagation worked very well in success fully delivering aquatic plant seeds into permanently inundated conditions.
\end{abstract}

Keywords Heavy Metals Contamination, In Situ Capping Material, Aquablok, Wetland Vegetation

\section{Introduction}

As a result of commercial and industrial activities conducted in the absence of environmental regulations and enforcement in the past, sediments contaminated by organic compounds, heavy metals, and other potentially toxic chemicals have accumulated in large quantities in the New Jersey Hackensack Meadowlands[1]. The contamination of marine and freshwater sediments with organic and inorganic pollutants has become a world wide problem with implications for human and ecological health[2]. The need for remediation or management of contaminated sediments has become increasingly evident Contaminated sediments can be managed in various ways: They can be removed by

* Alice Benzecry:

benzecry@fdu.edu (Alice Benzecry)

Published online at http://journal.sapub.org/ajee

Copyright (C) 2012 Scientific \& Academic Publishing. All Rights Reserved dredging and treated ex-situ, as appropriate, prior to disposal. The sediments can also be managed in-situ by capping, or treatment by biolog ical or chemical means. Am ong these techniques, treatment of contaminated sediment sites with in-situ caps has become an established practice that can provide advantages over other alternative methods [3].

Advantages of in-situ capping relative to sediment remov al include minimal environmental and habitat disturbance, minimal sediment exposure and handling, minimal release of volatile organics and elimination of the need for disposal facilities, resulting in lower remediation costs. In addition, in-situ sediment caps are relatively easy to construct, repair or replace as part of ongoing operation and maintenance.

Clean sand has traditionally been employed as capping material and remains a large component of many field-scale capping applications. Sand-based caps have the potential to delay contaminant breakthrough when diffusive transport dominates[4-5], but eventual contaminant breakthrough 
remains a source of concern. Additionally, traditional sand caps are less effective at sites where groundwater seepage or mobile contaminants are present[4].

Recent research studies have focused on in-situ sequestra tion[6-7], in-situ transformation[8-9] and the development of active caps that incorporate reactive and/or absorptive constituents designed to reduce contaminant and bioavailabi lity[6],[10-14]. Ideally, active caps eliminate the risk of contaminant breakthrough into the overlying water column, and can potentially be implemented as alternative sediment.

The objectives of this laboratory research were to:

1) Test the ability of a patented "active cap" i.e. AquaBlok (AB) to serve as physical barrier between contaminated sediments and overlying biological receptors. 2) Evaluate the ability of plants to colonize $\mathrm{AB}$ as an alternative to sediment. 3) Determine if adding organic matter (2\% peat) improved AB's suitability as a substrate. 4 ) Evaluate the effectiveness of AB pellet (SubmerSeeds) as an alternative tool for plant propagation in permanently inundated waters.

\subsection{Why AquaBlok ${ }^{\text {TM }}$}

AquaBlok (AB)[15] is a commercial patented, clay mineral-based composite aggregate technology comprised of a solid core (typically stone aggregate), an outer layer of clay material (bentonite) and polymers. Bentonite, which is well known and widely used throughout the environmental industry, comprises the primary clay material for typical freshwater product formulations, however, other clay or quasi clay-sized materials such as organic matter or plant seeds (Composite Seeding Technology "SubmerSeeds"TM") can also be incorporated into product formulations as needed. Empirical and preliminary laboratory data from the manufacturing industry indicate that $\mathrm{AB}[16]$ not only serves as a physical barrier between sediments and overlying biological receptors but it can also serve as a benthic substrate for flora and fauna colonization[17].

Based on a series of EPA reports[18-19], AB has distinct advantages over sand for sediment capping with respect to meeting targeted remedial capping functions. It offers physical and chemical blocking of contaminant pathways to overlying receptor organisms and minimizes adverse impacts to wetland hydrology. Granular materials (e.g., sand) can serve as appropriate and adequate capping materials at many sediment remediation sites[20]. Granular materials are typically inexpensive, often locally available, relatively easy to place and can provide substrate for marsh biota. However, typical granular materials are also relatively easily eroded and permeable to the diffusive and adverting movement of dissolved sediment-borne contaminants[21]. Additionally, sand-based remedial caps are often relatively thick (i.e. on the order of feet rather than inches) in order to adequately overcome these performance limitations. Relatively thick caps may adversely affect waterway navigation at some deepwater sites or adversely impact the hydrology and vegetative communities in wetland ecosystems [22-23]. Finer-grained materials (e.g., clays) are typically more cohesive, less permeable, and more reactive than sands. A relatively thin clay-based cap (i.e. on the order of inches rather than feet) can provide a better capping remedy that is less disruptive of wetland quality and function. Additionally, clay has a higher cation exchange capacity than sand making it more effective in trapping contaminants such as heavy metals.

The addition of plants seeds into their formulation Composite Seeding Technology "SubmerSeeds ${ }^{\mathrm{TM}}$ " creates an attractive alternative to traditional means of plant propagation in wetland/aquatic settings, especially when confronted with the challenges of establishing a favourable vegetative commun ity in permanently inundated conditions.

\section{Experimental Design}

To study the effectiveness of AquaBlok (AB) and AquaBlok amended with $2 \%$ peat moss (ABPM) as in-situ "active" capping material and benthic substrate for wetland biota in a greenhouse setting, a total of six 100 gallon tubs containing Hackensack Meadowlands soil and water were used during a two year period. Wetland vegetation seeds of 28 common regional species (Table 1) were incorporated into the AquaBlok formulation to produce SubmerSeed ${ }^{\mathrm{TM}}$.

Table 1. SubmerSeed composition

\begin{tabular}{|c|c|c|c|}
\hline Botanical Name & Oz. & Botanical Name & Oz. \\
\hline Carex comosa & 2.5 & Decodon verticillatus & 1.25 \\
\hline Carex lacustris & 0.2 & Eupatorium maculat um & 0.50 \\
\hline Carex lurida & 4.0 & Hibiscus spp. & 3.00 \\
\hline Carex vulpinoidea & 6.0 & Iris virginica & 6.00 \\
\hline Eleocharis ovata & 1.0 & Lobelia cardinalis & 0.25 \\
\hline Juncus effusus & 1.0 & Lobelia siphilitica & 1.50 \\
\hline Leersia orzyoides & 3.0 & Ludwigia alternifolia & 0.25 \\
\hline Scirpus acutus & 2.5 & Mimulus ringens & 1.00 \\
\hline Scirpus pungens & 4.0 & Cephalanthus spp. & 1.00 \\
\hline Scirpus validus & 6.0 & Peltandra virginica & 16.0 \\
\hline Acorus calamus & 1.0 & Pontederia cordata & 10.0 \\
\hline Asclepias incarnata & 1.5 & Sagittaria latifolia & 2.00 \\
\hline Alisma subcordatum. & 3.0 & Thypha angustifolia & 2.00 \\
\hline Zizania aquatica & 8.0 & Sparganium spp. & 4.00 \\
\hline
\end{tabular}

Replica sediment samples from different areas representing the marsh were collected from the New Jersey Hackensack Meadowlands Marsh. Pre-capping sediments were characterized by measuring $\%$ mo isture and $\%$ total organic carbon (TOC) (ASTM-D2974[24]), grain size (ASTM-D422[25]) and heavy metals of concern (HMOC) (SW 846 Method 7000A[26]).

Each experimental tubs received one of three treatments in duplicate: Treatment 1 (Soil) consisting of Hackensack Meadowlands Marsh sediment (sufficient to fill the tub to the 22" mark). Treatment 2 (AB) consisting of Hackensack Meadowlands Marsh sediment (suffic ient to fill the tub to the 
13" mark) and $150 \mathrm{lb}$ of $\mathrm{AB}$ ( 8 " hydrated). Treatment 3 (ABPM) consisting of Hackensack Meadowlands Marsh sediment (sufficient to fill the tub to the 13" mark) and $150 \mathrm{lb}$ of ABPM (8" hydrated). All tubs were filled with Hackensack Meadowlands Marsh water to the rim mark. Marsh sediments and water were allowed to settle on the tubs for two weeks before capping. Once the cap had completely hydrated to 8"-9", approximately one week, wetland plant species were sown into the tubes in the form of $1 \frac{1 / 2}{\mathrm{lb}}$ of SubmerSeeds as per the manufacture recommendations.

At the end of each growing season, plants were harvested and characterized based on their numbers, size, dry weight, and root system. Plant tissues as well as sediments in the tubs were monitored for HMOC using the SW 846 Method 7000A[26].

\section{Initial pre-capping analysis}

Tables 2 and 3 represent the Meadowlands sediments characterizations including percent moisture, ash content (Ash), total organic matter (TOC) and grain sizes. The average percentage moisture of the sediment was $91.1 \%$, ash content varied from $11.9 \%$ to $15.2 \%$, and the average total organic matter content was $86.31 \%$ (Table 2).
Table 2. Characterization of Meadowlands marsh sediments based on AST M-D2974[24]; percent moisture, ash content (Ash) and total organic matter (TOC)

\begin{tabular}{|c|c|c|c|}
\hline Sample & \% moisture & \% Ash & \% T OC \\
\hline 1 & 92.8 & 11.9 & 88.1 \\
\hline 2 & 91.3 & 15.1 & 84.9 \\
\hline 3 & 90.8 & 13.6 & 86.4 \\
\hline 4 & 90.1 & 13.1 & 86.9 \\
\hline 5 & 90.5 & 13.2 & 86.8 \\
\hline 6 & 91.1 & 15.2 & 84.8 \\
\hline Average & 91.1 & 13.68 & 86.31 \\
\hline
\end{tabular}

The grain size distribution included $50.59 \%$ of sand (coarse, medium, fine and very fine), $33.48 \%$ silt, $13.92 \%$ clay and $2.19 \%$ of pebbles and granules (Table 3).Heavy metals of concern present in sediment during the initial collection are presented on Table 4. Based on the Ontario Aquatic Sediment Criterion[27] concentrations for all initial HMOC were above LEL (Lowest Effects Limit) with $\mathrm{Cu}$ $(281.66 \mathrm{mg} / \mathrm{Kg})$ and $\mathrm{Pb}(392.86 \mathrm{mg} / \mathrm{Kg})$ concentrations being above SEL (Severe Effects Limit).

Table 3. Meadowlands marsh sediment samples grain sizes characterization based on AST M-D422[25]

\begin{tabular}{|c|c|c|c|c|c|c|c|c|}
\hline & Pebble & Granule & Coarse Sand & $\begin{array}{c}\text { Medium } \\
\text { Sand }\end{array}$ & Fine Sand & $\begin{array}{c}\text { Very Fine } \\
\text { Sand }\end{array}$ & Silt & Clay \\
\hline 1 & $0.10 \%$ & $0.44 \%$ & $11.73 \%$ & $17.56 \%$ & $18.23 \%$ & $11.37 \%$ & $25.92 \%$ & $14.64 \%$ \\
\hline 2 & $0.23 \%$ & $3.29 \%$ & $11.86 \%$ & $8.44 \%$ & $11.32 \%$ & $10.00 \%$ & $40.21 \%$ & $14.66 \%$ \\
\hline 3 & $1.64 \%$ & $2.20 \%$ & $16.40 \%$ & $11.69 \%$ & $12.98 \%$ & $9.63 \%$ & $33.00 \%$ & $13.54 \%$ \\
\hline 4 & $0.22 \%$ & $2.38 \%$ & $13.84 \%$ & $13.71 \%$ & $14.40 \%$ & $8.10 \%$ & $34.79 \%$ & $12.55 \%$ \\
\hline 5 & $0.29 \%$ & $1.41 \%$ & $11.11 \%$ & $15.23 \%$ & $15.97 \%$ & $9.48 \%$ & $30.65 \%$ & $15.87 \%$ \\
\hline 6 & $0.06 \%$ & $0.88 \%$ & $11.49 \%$ & $14.87 \%$ & $14.05 \%$ & $10.09 \%$ & $36.31 \%$ & $12.24 \%$ \\
\hline Average & $0.42 \%$ & $1.77 \%$ & $12.74 \%$ & $13.58 \%$ & $14.49 \%$ & $9.78 \%$ & $33.48 \%$ & $13.92 \%$ \\
\hline
\end{tabular}

Table 4. Meadowlands marsh sediment analyses of Heavy metals of concern in $(\mathrm{mg} / \mathrm{Kg})$ based on SW 846 Method 7000A[26]

\begin{tabular}{|c|c|c|c|c|c|c|c|}
\hline Site & $\mathrm{Cd}$ & $\mathrm{Cr}$ & $\mathrm{Cu}$ & $\mathrm{Hg}$ & $\mathrm{Ni}$ & $\mathrm{Pb}$ & $\mathrm{Zn}$ \\
\hline 1 & 3.19 & 80.6 & 237 & 1.07 & 58.1 & 459 & 534 \\
\hline 2 & 4.69 & 74.7 & 261 & 2.47 & 56.3 & 416 & 589 \\
\hline 3 & 3.75 & 116 & 329 & 1.03 & 76 & 473 & 606 \\
\hline 4 & 4.84 & 88.4 & 342 & 1.98 & 69.4 & 478 & 810 \\
\hline 5 & 4.86 & 87.4 & 329 & 2.13 & 70.6 & 449 & 712 \\
\hline 6 & 4.22 & 43.8 & 192 & 1.62 & 62.6 & 78.6 & 757 \\
\hline Average & 4.25 & 81.81 & 281.66 & 1.72 & 65.5 & 392.26 & 668 \\
\hline LEL & 0.6 & 26 & 16 & 0.2 & 16 & 31 & 120 \\
\hline SEL & 10 & 110 & 110 & 2 & 75 & 250 & 820 \\
\hline
\end{tabular}




\section{Post-capping analysis}

\subsection{Plant Growth}

A limited number of species of marsh vegetation were able to germinate in the test substrate; only six of the original 28 species prepared as SubmerSeeds: Zizania aquatica,

Alisma subcordatum, Typha angustifolia, Peltandra virginica, Scirpus validus and Scirpus spp.. Large numbers of seedlings of Peltandra virginica, Scirpus validus and Scirpus spp. germinated but were not able to reach full maturity. Due to the low numbers of established matured representatives of these species, they were not fully considered under this study.

During the first growing season, wetland vegetation grew better in uncapped sediments when compared to AquaBlok capped sediments. Zizania aquatica, Alisma subcordatum and Typha angustifolia germinated and developed better in ABPM when compared to AB alone. In addition to the above-mentioned species, Phragmites australis from the local seed/rhizo me banks equally colonized both capped and uncapped sediments (Figure 1)

Observations of wetland vegetation during the second growing seas on revealed that plant germination and growth rates in ABPM declined considerably when compared to the $\mathrm{AB}$ and Soil treatments (Figure 1).

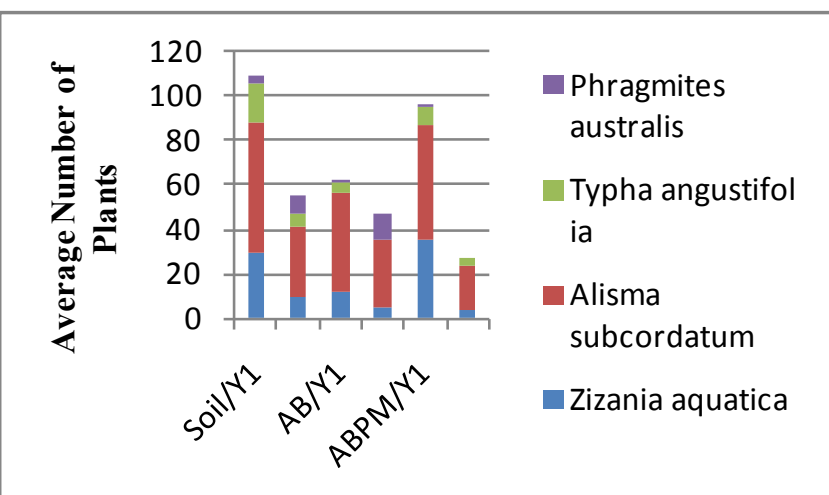

Figure 1. Average number of plants that germinated and reached mat urity at the different treatments; Soil, AB and ABPM. Y1=first growing season, $\mathrm{Y} 2=$ second growing season
Plants growing in AquaBlok (AB and ABPM) as alternative sediment source were less robust than plants growing in Soil (uncapped sediment control) (Figure. 2 and Table 5).

The average plant dry weight growing in soil, (control) was $3.8 \mathrm{~g} / \mathrm{plant}$ for Zizania aquatica, 5.4g/plant for Alisma subcordatum, $12.9 \mathrm{~g} / \mathrm{plant}$ for Typha angustifolia and 158.5gr/plant for Phragmites australis. Plants growing in AquaBlok (AB and ABPM) have produced smaller plants with lower dry weight when compared to those growing in soil (Figure 2 and Table 5); $1.2 \mathrm{~g} /$ plant and $1.33 \mathrm{~g} /$ plant for Zizania aquatic, 2.1g/plant and $1.7 \mathrm{~g} / \mathrm{plant}$ for Alisma subcordatum, and $10.1 \mathrm{gm} /$ plant for Typha angustifolia.

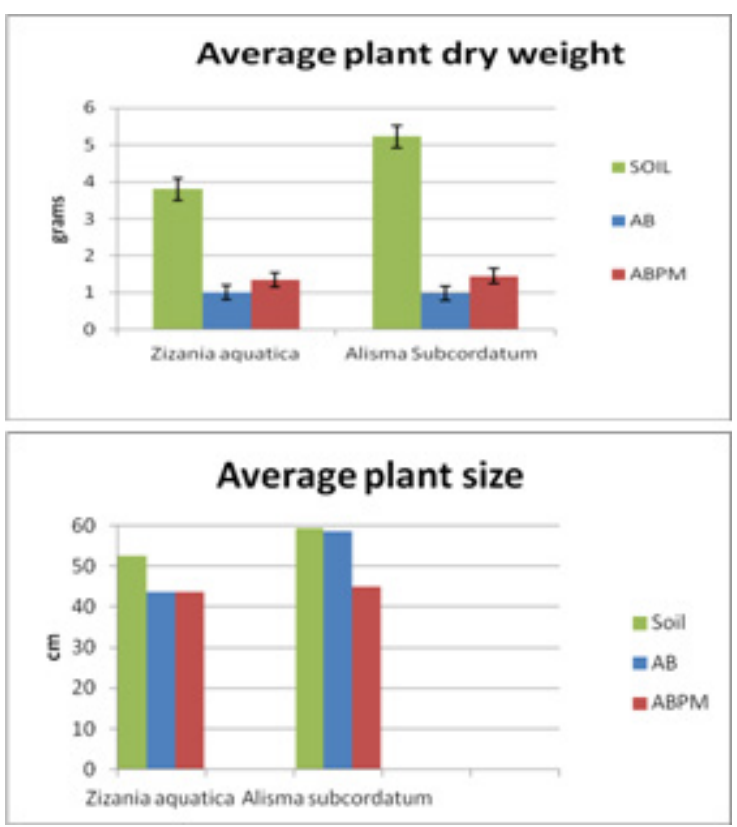

Figure 2. Average size and dry weight of two plant species representatives growing in different treatments. Soil, AB and ABPM

When further examining the vegetation growth patterns, a dramatic decrease in leaf sizes (Figure 3) and root development (Figure 4) were observed in plants growing in AquaBlok (AB and ABPM) capped sediments tubs when compared to the same vegetation growing in uncapped marsh sediment (soil).

Table 5. Average size and dry weigh of dominant plants growing at different treatments. Soil, $A B$ and $A B P M$. NG= no growth. $Y 1=$ first Growing season, $\mathrm{Y} 2=$ second growing season

\begin{tabular}{|c|c|c|c|c|c|c|}
\hline Plant Species & \multicolumn{2}{|c|}{ SOIL } & \multicolumn{2}{c|}{ AB } & \multicolumn{2}{c|}{ ABPM } \\
\hline & Average size & $\begin{array}{c}\text { Average dry } \\
\text { weight }\end{array}$ & Average size & $\begin{array}{c}\text { Average dry } \\
\text { weight }\end{array}$ & $\begin{array}{c}\text { Average size } \\
\text { Average dry } \\
\text { weight }\end{array}$ \\
\hline Zizania aquatic Y1 & $52.6 \mathrm{~cm}$ & $3.8 \mathrm{gr}$ & $43.6 \mathrm{~cm}$ & $1.2 \mathrm{gr}$ & $43.7 \mathrm{~cm}$ & $1.33 \mathrm{gr}$ \\
\hline Alisma subcordatum Y1 & $59.3 \mathrm{~cm}$ & $5.8 \mathrm{gr}$ & $58.7 \mathrm{~cm}$ & $5.8 \mathrm{gr}$ & $44.9 \mathrm{~cm}$ & $5.6 \mathrm{gr}$ \\
\hline Alisma subcordatum Y2 & $58.9 \mathrm{~cm}$ & $5.4 \mathrm{gr}$ & $59.8 \mathrm{~cm}$ & $2.1 \mathrm{gr}$ & $42.2 \mathrm{~cm}$ & $1.7 \mathrm{gr}$ \\
\hline Typha angustifolia Y2 & $92.2 \mathrm{~cm}$ & $12.9 \mathrm{gr}$ & $\mathrm{NG}$ & $\mathrm{NG}$ & $74.4 \mathrm{~cm}$ & $10.1 \mathrm{gr}$ \\
\hline Phragmites australis Y2 & $158.5 \mathrm{~cm}$ & $14.7 \mathrm{gr}$ & $162.7 \mathrm{~cm}$ & $27.9 \mathrm{gr}$ & $\mathrm{NG}$ & NG \\
\hline
\end{tabular}




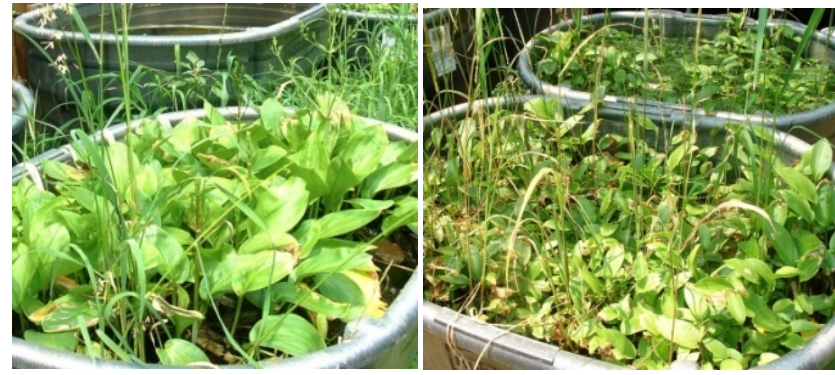

Uncapped soil treatment Capped AB and ABPM treatments

Figure 3. plants growing in the different treatments: Soil, AB and ABPM

While growing within the AquaBlok, roots appeared attached to the aggregate core of the SubmerSeeds and continued to be heavily covered by the clay; this being more noticeable in the AB than in ABPM (Figure 4).
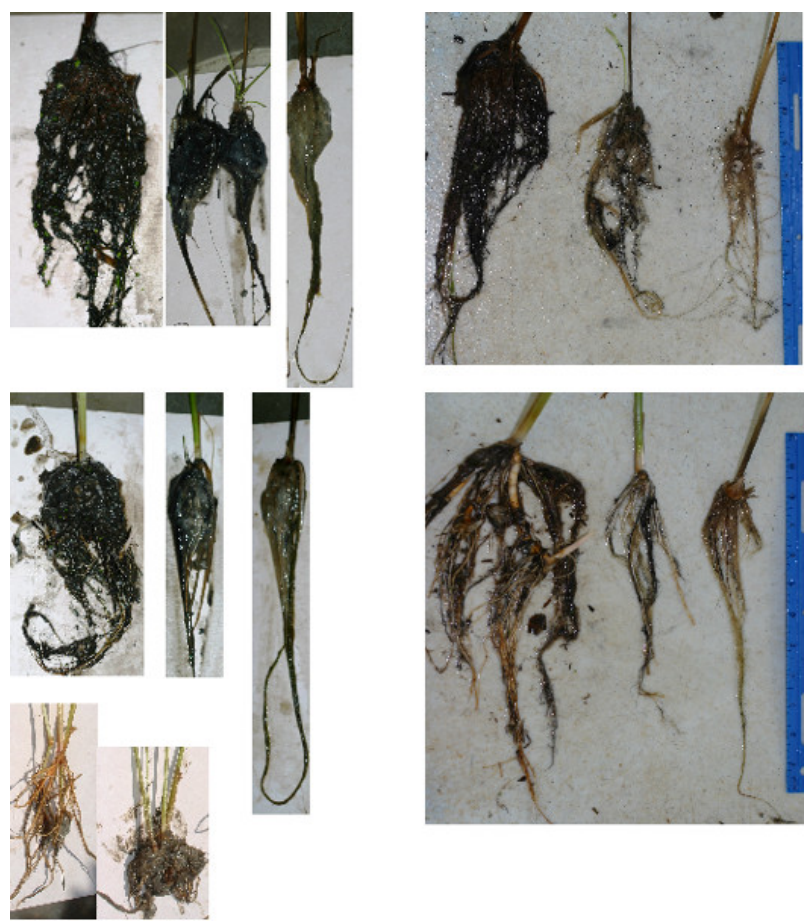

Figure 4. Top left $=$ roots of Alisma subcordatum growing in soil, ABPM and $\mathrm{AB}$. Top right = same roots after heavy washing to remove the clay. Middle = roots of Typha angustifolia growing in soil, ABPM and AB. Middle right $=$ same roots after heavy washing to remove the clay. Bottom left= roots of Zizania aquatica growing in soil and ABPM

\subsection{Heavy Metals of Concern}

Heavy metal of concern concentrations in sediment shows treatment related effects (Figure 5). Total metal concentrati ons in AquaBlok (AB and ABPM) treated tubs declined significantly after capping from $1496.83 \mathrm{mg} / \mathrm{Kg}$ to 330.70 $\mathrm{mg} / \mathrm{Kg}$ in $\mathrm{AB}$ and $315.18 \mathrm{mg} / \mathrm{Kg}$ in ABPM. In uncapped tubs (soil), s ediment concentrations of $\mathrm{Cu}(450.67 \mathrm{mg} / \mathrm{Kg})$ and $\mathrm{Pb}$ $(460.63 \mathrm{mg} / \mathrm{Kg})$ were consistently above their SEL and $\mathrm{Hg}$ $(1.21 \mathrm{mg} / \mathrm{Kg})$ and $\mathrm{N}(45.72 \mathrm{mg} / \mathrm{Kg})$ were above LEL when compared to capped sediment tubs. $\mathrm{Cd}$ and $\mathrm{Hg}$ was above LEL in all tubes, uncapped soil had twice as much $\mathrm{Cd}$ and five times more $\mathrm{Hg}$ than capped ones. Uncapped sediments had 5 to 6 times more $\mathrm{Cr}$ and $\mathrm{Cu}$ than capped sediments. Ni quantities above ELE in uncapped sediments were five and one half times higher than capped sediments. $\mathrm{Pb}$ levels above SEL in uncapped sediments were also five and one half times higher than capped sediments.

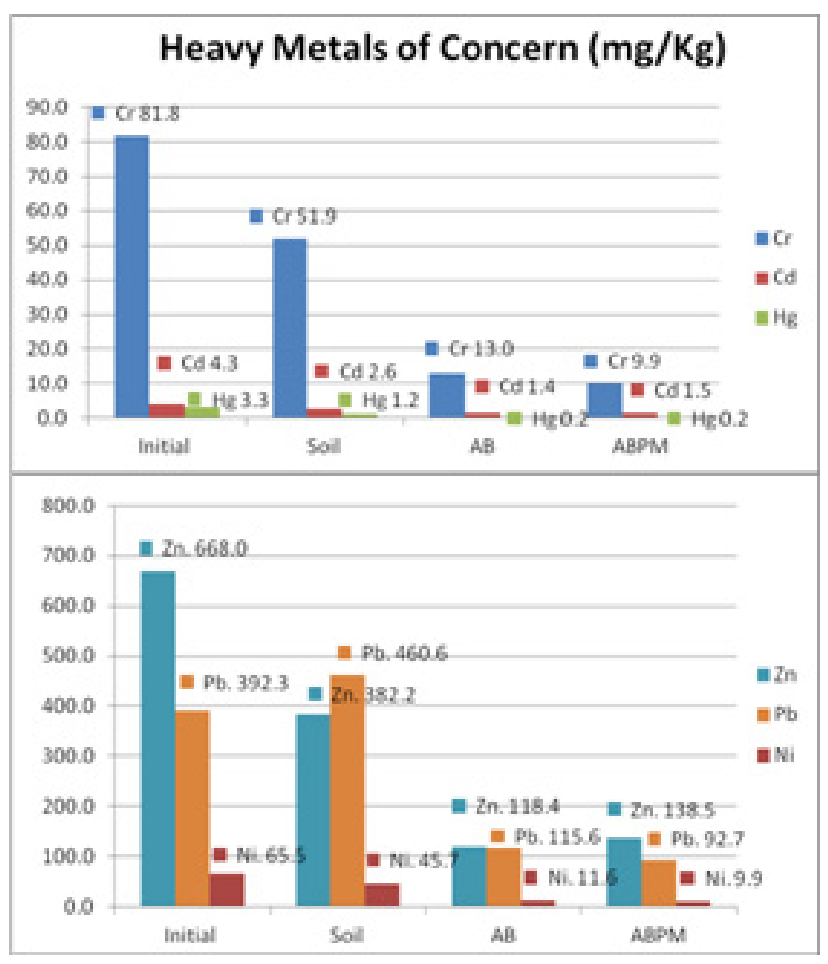

Figure 5. Amounts of heavy metals of concern variation in sediments at the different experimental treatments (Soil, $\mathrm{AB}$ and $\mathrm{ABPM}$ ) before (initial) and aftertwo veget ation growing seasons

Table 6 summarizes the amount of heavy metals of concern concentrated in sediments and plant material grown within each of the treatments during two growing seasons.

Cadmium amounts varied from $0.427 \mathrm{mg} / \mathrm{kg}$ in Phragmites australis growing on ABPM to $7.084 \mathrm{mg} / \mathrm{kg}$ in Alisma Subcordatum growing in marsh soil. Chromium amounts varied from $4.23 \mathrm{mg} / \mathrm{kg}$ in Alisma Subcordatum growing in $\mathrm{AB}$ to $34.78 \mathrm{mg} / \mathrm{kg}$ in Alisma Subcordatum growing in marsh soil. Copper amounts varied from 29.528 $\mathrm{mg} / \mathrm{kg}$ in Alisma Subcordatum growing in AB to 209.312 $\mathrm{mg} / \mathrm{kg}$ in Alisma Subcordatum growing in marsh soil. Mercury concentrations varied from $0.16 \mathrm{mg} / \mathrm{kg}$ in Phragmites australis growing in ABPM to $4.83 \mathrm{mg} / \mathrm{kg}$ in Alisma Subcordatum growing in marsh soil. Nickel concentrations varied from $7.89 \mathrm{mg} / \mathrm{kg}$ in Alisma Subcordatum growing in AB to $40.78 \mathrm{mg} / \mathrm{kg}$ in Alisma Subcordatum growing in marsh soil. Lead concentrations varied from $45.903 \mathrm{mg} / \mathrm{kg}$ in Alisma Subcordatum growing in AB to $334.301 \mathrm{mg} / \mathrm{kg}$ in Alisma Subcordatum growing in marsh soil. Zink concentrations varied from $142.65 \mathrm{mg} / \mathrm{kg}$ in Alisma Subcordatum growing in A B to $729.388 \mathrm{mg} / \mathrm{kg}$ in Alisma Subcordatum growing in marsh soil.

Vegetation growing at the different sediment treatments (soil, AB and ABPM) showed great variation in the amounts of HMOC in their tissues (Figure 6). 
Table 6. Heavy metals concentrations $(\mathrm{mg} / \mathrm{kg}$ ) in substrate and plants. Soil= control (no cap), $\mathrm{AB}=\mathrm{AquaBlok}, \mathrm{ABP} M=2 \%$ peat moss amendment, $\mathrm{Y} 1=$ first growing season, $\mathrm{Y} 2=$ second growing season. Total= sum of metals without $\mathrm{Fe}$

\begin{tabular}{|c|c|c|c|c|c|c|c|c|c|c|c|}
\hline Species & Treatment & Description & $\mathrm{Cd}$ & $\mathrm{Cr}$ & $\mathrm{Cu}$ & $\mathrm{Fe}$ & $\mathrm{Hg}$ & $\mathrm{Ni}$ & $\mathrm{Pb}$ & $\mathrm{Zn}$ & Total \\
\hline Substrate before Planting & SOIL & Initial substrate & 4.258 & 81.81 & 281.66 & 46407.6 & 3.322 & 65.5 & 392.26 & 668 & 1496.8 \\
\hline AfterPlanting & SOIL & End substrate & 2.56 & 51.885 & 450.671 & 23235.4 & 1.21 & 45.728 & 460.638 & 382.219 & 1394.9 \\
\hline \multirow[t]{3}{*}{ Zizania aquatica } & SOIL & Stem/leaf & 0.47 & 3.01 & 4.47 & 209.17 & 0.67 & 0.86 & 5.97 & 87.84 & 103.29 \\
\hline & & Roots & 1.775 & 20.345 & 119.631 & 21219.4 & 0.297 & 17.34 & 137.238 & 253.826 & 550.45 \\
\hline & & Total & 2.245 & 23.355 & 124.101 & 21428.6 & 0.967 & 18.2 & 143.208 & 341.666 & 653.74 \\
\hline \multirow[t]{4}{*}{ Alisma subcordatum } & SOIL & Leaves & 0.97 & 3.772 & 26.66 & 1188.24 & 0.184 & 3.371 & 16.98 & 202.138 & 254.07 \\
\hline & & Stems & 0.57 & 1.47 & 14.13 & 232.58 & 0.14 & 1.15 & 5.19 & 50.28 & 72.93 \\
\hline & & Roots & 5.543 & 21.53 & 150.15 & 36200.7 & 0.255 & 25.262 & 223.539 & 476.97 & 903.24 \\
\hline & & Total & 7.084 & 26.772 & 190.94 & 37621.6 & 0.579 & 29.783 & 245.709 & 729.388 & 1230.2 \\
\hline \multirow{4}{*}{ Alisma subcordatum } & SOIL & Leaves & 1.069 & 14.984 & 65.956 & 16291.4 & 4.31 & 15.494 & 94.006 & 229.343 & 425.16 \\
\hline & & Stems & 0.169 & 0.92 & 6.266 & 161.899 & 0.191 & 2.259 & 1.603 & 22.813 & 34.219 \\
\hline & & Roots & 1.93 & 18.88 & 137.091 & 29549.4 & 0.33 & 23.031 & 238.692 & 347.383 & 767.33 \\
\hline & & Total & 3.167 & 34.784 & 209.312 & 46002.8 & 4.831 & 40.784 & 334.301 & 599.539 & 1226.7 \\
\hline \multirow{4}{*}{$\begin{array}{l}\text { Typha angust ifolia } \\
\text { (Y2) }\end{array}$} & SOIL & Leaves & 0.128 & 10.25 & 6.956 & 450.645 & 0.068 & 4.512 & 4.862 & 35.692 & 62.469 \\
\hline & & Stems & 0.482 & 1.343 & 14.595 & 997.382 & 0.121 & 1.784 & 7.052 & 95.167 & 120.54 \\
\hline & & Roots & 3.21 & 11.644 & 84.694 & 17567.4 & 0.194 & 10.263 & 177.706 & 369.354 & 657.06 \\
\hline & & Total & 3.821 & 23.237 & 106.245 & 19015.4 & 0.384 & 16.559 & 189.621 & 500.213 & 840.08 \\
\hline \multirow[t]{4}{*}{ Phragmatis sp (Y2) } & SOIL & Leaves & 0.065 & 2.806 & 8.205 & 461.13 & 0.03 & 2.584 & 5.471 & 48.391 & 67.552 \\
\hline & & Stems & 0.271 & 8.924 & 9.881 & 731.774 & 0.023 & 4.275 & 9.05 & 49.666 & 82.092 \\
\hline & & Roots & 1.852 & 5.691 & 54.098 & 17838.9 & 1.86 & 7.406 & 119.14 & 170.995 & 361.04 \\
\hline & & Total & 2.187 & 17.422 & 72.184 & 19031.8 & 1.913 & 14.265 & 133.662 & 269.052 & 510.68 \\
\hline AfterPlanting & $\mathrm{AB}$ & End substrate & 1.358 & 12.955 & 70.57 & 13121.4 & 0.22 & 11.585 & 115.576 & 118.443 & 330.70 \\
\hline \multirow[t]{3}{*}{ Zizania aquatica } & $\mathrm{AB}$ & Stem/leaf & 0.369 & 5.635 & 5.909 & 541.479 & 0.29 & 2.416 & 11.974 & 115.62 & 142.21 \\
\hline & & Roots & 1.528 & 19.676 & 33.763 & 8335.28 & ND & 8.746 & 54.746 & 282.055 & 400.51 \\
\hline & & Total & 1.897 & 25.311 & 39.671 & 8876.76 & 0.29 & 11.162 & 66.72 & 397.675 & 542.72 \\
\hline \multirow[t]{4}{*}{ Alisma subcordat um } & $\mathrm{AB}$ & Leaves & 0.723 & 2.379 & 20.327 & 377.571 & 0.109 & 1.535 & 9.936 & 130.726 & 165.73 \\
\hline & & Stems & 0.356 & 2.075 & 15.896 & 416.075 & ND & 0.879 & 8.587 & 86.446 & 114.23 \\
\hline & & Roots & 1.191 & 4.783 & 26.402 & 8439.25 & 0.173 & 5.455 & 49.705 & 159.445 & 247.15 \\
\hline & & Total & 2.271 & 9.237 & 62.625 & 9232.89 & 0.282 & 7.869 & 68.228 & 376.618 & 527.12 \\
\hline \multirow{4}{*}{$\begin{array}{l}\text { Alisma subcordat um } \\
\text { (Y2) }\end{array}$} & $\mathrm{AB}$ & Leaves & 0.329 & 1.278 & 10.592 & 628.875 & 1.382 & 2.983 & 6.903 & 43.923 & 67.39 \\
\hline & & Stems & 0.235 & 0.508 & 4.26 & 168.664 & 0.65 & 8.637 & 1.015 & 20.999 & 36.305 \\
\hline & & Roots & 0.565 & 2.444 & 14.676 & 6145.98 & 0.056 & 6.282 & 37.984 & 77.736 & 139.74 \\
\hline & & Total & 1.129 & 4.231 & 29.528 & 6943.52 & 2.088 & 17.903 & 45.903 & 142.657 & 243.43 \\
\hline \multirow[t]{4}{*}{ Phragmat is sp (Y2) } & $\mathrm{AB}$ & Leaves & 0.042 & 7.155 & 3.94 & 228.301 & 0.048 & 4.009 & 5.099 & 65.143 & 85.435 \\
\hline & & Stems & 0.081 & 1.303 & 8.13 & 896.878 & 0.039 & 0.654 & 7.206 & 69.194 & 86.607 \\
\hline & & Roots & 0.304 & 5.537 & 38.66 & 9240.51 & 0.074 & 4.598 & 46.94 & 89.751 & 185.86 \\
\hline & & Total & 0.427 & 13.995 & 50.729 & 10365.7 & 0.162 & 9.261 & 59.245 & 224.089 & 357.90 \\
\hline \multirow{4}{*}{$\begin{array}{c}\text { After Planting } \\
\text { Zizania aquatica }\end{array}$} & ABPM & End substrate & 1.488 & 9.894 & 62.481 & 11282.0 & 0.228 & 9.917 & 92.718 & 138.455 & 315.18 \\
\hline & ABPM & Stem/leaf & 0.631 & 3.078 & 7.67 & 274 & 0.05 & 1.694 & 9.088 & 117.582 & 139.79 \\
\hline & & Roots & 1.064 & 8.012 & 20.784 & 17665.6 & 0.134 & 7.428 & 47.247 & 223.313 & 307.98 \\
\hline & & Total & 1.695 & 11.09 & 28.454 & 17939.6 & 0.184 & 9.122 & 56.335 & 340.895 & 447.77 \\
\hline \multirow[t]{4}{*}{ Alisma subcordatum } & ABPM & Leaves & 0.863 & 5.902 & 16.8 & 665.27 & 0.022 & 2.157 & 10.952 & 129.845 & 166.54 \\
\hline & & Stems & 0.341 & 1.867 & 13.276 & 180.339 & ND & 1.609 & 7.658 & 55.799 & 80.549 \\
\hline & & Roots & 2.324 & 12.124 & 24.093 & 2938.02 & 1.505 & 8.492 & 48.783 & 102.971 & 200.29 \\
\hline & & Total & 3.527 & 19.893 & 54.17 & 3783.63 & 1.527 & 12.258 & 67.392 & 288.615 & 447.38 \\
\hline \multirow[t]{4}{*}{ Alisma subcordatum } & ABPM & Leaves & 0.414 & 5.393 & 8.609 & 1337.83 & 0.173 & 5.686 & 17.297 & 76.846 & 114.41 \\
\hline & & Stems & 0.957 & 6.15 & 4.916 & 164.569 & 0.097 & 2.772 & 1.275 & 26.998 & 43.165 \\
\hline & & Roots & 1.224 & 3.767 & 20.009 & 7321.15 & 0.079 & 5.92 & 41.572 & 142.408 & 214.98 \\
\hline & & Total & 2.595 & 15.31 & 33.534 & 8823.55 & 0.349 & 14.378 & 60.144 & 246.252 & 372.56 \\
\hline \multirow[t]{4}{*}{ Typha angustifolia (Y2) } & ABPM & Leaves & 0.658 & 3.204 & 7.534 & 217.269 & 0.108 & 2.498 & 4.123 & 22.828 & 40.955 \\
\hline & & Stems & 0.903 & 0.763 & 9.091 & 237.322 & 0.014 & 0.946 & 6.082 & 47.125 & 64.924 \\
\hline & & Roots & 3.474 & 8.325 & 122.188 & 26052.3 & 0.202 & 10.627 & 149.46 & 232.971 & 527.24 \\
\hline & & Total & 5.035 & 12.292 & 138.813 & 26506.9 & 0.325 & 14.071 & 159.665 & 302.923 & 633.12 \\
\hline \multirow[t]{4}{*}{ Phragmatis sp (Y2) } & ABPM & Leaves & 0.507 & 2.282 & 9.113 & 977.624 & 0.102 & 2.3 & 12.153 & 56.894 & 83.351 \\
\hline & & Stems & 1.711 & 0.929 & 7.626 & 96.023 & 0.089 & 1.33 & 2.592 & 36.51 & 50.787 \\
\hline & & Roots & 2.315 & 3.184 & 93.542 & 3427.08 & 0.095 & 4.718 & 26.129 & 78.076 & 208.05 \\
\hline & & Total & 4.533 & 6.395 & 110.281 & 4500.73 & 0.286 & 8.348 & 40.874 & 171.48 & 342.19 \\
\hline
\end{tabular}




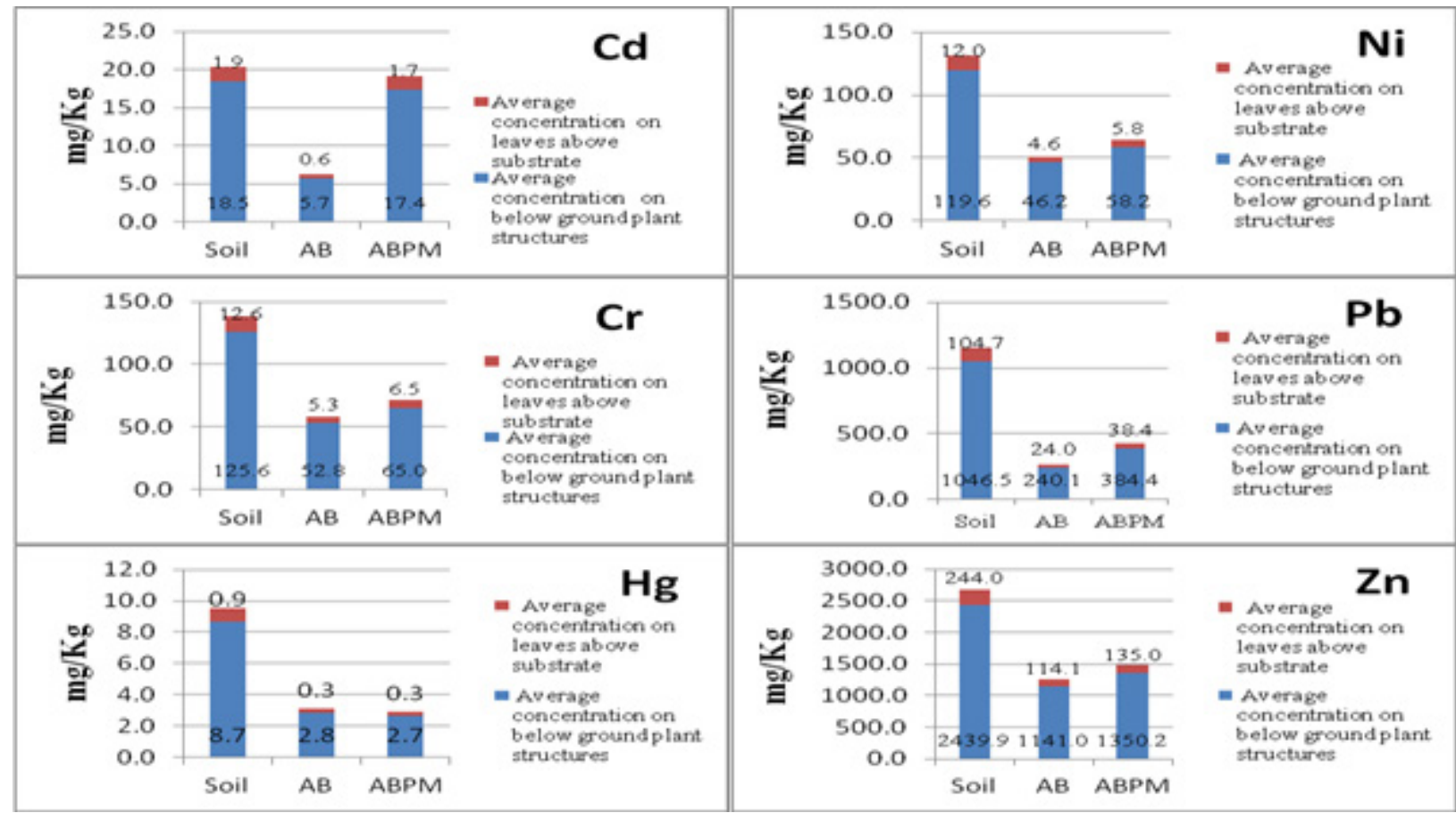

Figure 6. Amount sof heavy metalsof concern (HMOC) in plant tissues from representatives growing in the different experimental sediment treatments (Soil, AB and ABPM)

Most HMOC tended to accumulated in higher amounts in plants' underground structures (Figure 6). When growing in the control marsh soil Zizania aquatic accumulated 653.7 $\mathrm{mg} / \mathrm{kg}$ of heavy metals excluding $\mathrm{Fe}$, were $84 \%$ of that amount was found in their root tissues with exception of $\mathrm{Hg}$, which was found to be concentrated twice as much in the leaves and stems than the roots. While growing in $\mathrm{AB}$ and ABPM, the total accu mulation of HMOC were $542.76 \mathrm{mg} / \mathrm{kg}$ and $447.77 \mathrm{mg} / \mathrm{kg}$ respectively excluding $\mathrm{Fe}$, were $74 \%$ in $\mathrm{AB}$ and $69 \%$ in $\mathrm{ABPM}$ were found in the underground root tissue with exception of $\mathrm{Hg}$ which was not detected on roots growing in $\mathrm{AB}$.

Alisma Subcordatum when growing in marsh soil has a total excluding Fe of $1230.31 \mathrm{mg} / \mathrm{kg}$ of heavy metals in their tissues were $68 \%$ was found in their roots with exception of $\mathrm{Hg}$ where more than $80 \%$ of its total amount was found in the aboveground (leaves and stems) portion of the plants. When growing in $\mathrm{AB}$ and $\mathrm{ABPM}$, the total accumulation of HMOC was $343.43 \mathrm{mg} / \mathrm{kg}$ and $372.56 \mathrm{mg} / \mathrm{kg}$ and $58 \%$ of these metals were found in the belo wground structures of the plant. As in the plants growing in marsh soil, $\mathrm{Hg}$ concentrates mostly in the aboveground portion of the plants.

Typha angustifolia has accumulated $840.08 \mathrm{mg} / \mathrm{kg}$ of heavy metals excluding $\mathrm{Fe}$ while growing in marsh soil. From this total, more than $78 \%$ was found in their belowground structures. Most heavy metals were found in higher quantities approximately 4 times more in the roots than the leaves with exception of $\mathrm{Hg}$ and $\mathrm{Cr}$, which had similar amounts throughout the plant. When growing in $\mathrm{AB}$ and ABPM, very similar results were observed.

Phragmites australis like the other plants accumulated higher quantities ( 5 times more) of heavy metals in their underground portions (rhizomes and roots). From its 510.6 $\mathrm{mg} / \mathrm{kg}$ of total heavy metals excluding $\mathrm{Fe}, 84 \%$ was found in tis sues bellow the substrate surface with exception of $\mathrm{Hg}$.

\section{Conclusions}

Overall, capping provided a less contaminated substrate, $1496.83 \mathrm{mg} / \mathrm{Kg}$ total contaminant of concern versus 330.70 $\mathrm{mg} / \mathrm{Kg}$ in $\mathrm{AB}$ and $315.18 \mathrm{mg} / \mathrm{Kg}$ in ABPM. The concentrations of metals in the cap itself were much lower than in the sediments they covered. Co mparis on of collection dates showed no significant increase in heavy metals in the cap over a two-year period indicated that the heavy metals below the cap were not breaking through it. A mending the AquaBlok with peat moss (ABPM) did not significantly affect metal concentrations or plant growth. The initial germination and growth of plants in ABPM was better when compared to $\mathrm{AB}$ alone, but it quickly declined after the first growing season. In general, plants growing in $\mathrm{AB}$ and ABPM as an alternative sediment source were less robust than plants growing in uncapped sediments control (soil) despite the fact that they have smaller amounts of heavy metals in their tissues.

Most of the plants growing in the experimental tubs (soil, $\mathrm{AB}$ and $\mathrm{ABPM}$ ) concentrated higher amounts of heavy metals into their roots and/or underground portion of their stems, between 2.5 and 5 times more than the amounts concentrated in their aerial stems and leave. This is consistent with other research findings such as the works of Raskin et a1.[28], Sawidis et al.[29], Bennett et al.[30], and Reboreda and Caçador[31]. In all, the reduction of heavy metals provided by the capping material did not increase the 
growth or the health of vegetation in contaminated environment.

AquaBlok has proven to be an active barrier between contaminants and the biota. Nevertheless, it is not a good substrate for plant colonization despite the addition of organic matter ( $2 \%$ peat moss) to its formulation. Plants growing in AquaBlok capped sediments were less robust with lower dry weight and smaller root systems. The improvements of the clay mineral-based composite aggregate technology (SubmerSeeds) as an alternative to traditional means of plant propagation worked very well in success fully delivering aquatic plant seeds into permanently inundated conditions.

\section{ACKNOWLEDGMENTS}

This research was partially funded by an EPA grant XP 97287404-0 and Fairleigh Dickinson University faculty grant-in-aid.

Special thanks to Eduard Konsevick, Michael Pena, Louise Lynch, Kaitlin Le, Sameera Peddada, Anna Fauquet, and the Meadowlands Environmental Research Institute (MERI) lab personal for their help and contribution to this project.

\section{REFERENCES}

[1] Langan Engineering and Environmental Services, Inc., 1999. Environmental Assessment Report. Available as Document 1 at www.rerc.rutgers.edu/kearnymarsh/publications.html.

[2] USEPA (US Environmental Protection Agency), 1997. Ecological risk assessment guidance for Superfund: process for designing and conducting ecological risk assessment. U.S. Environmental Protection Agency, Washington, D.C (1997) EPA/540/R-97/006

[3] D. Reible, , D. Hay es, C. Lue-Hing, J. Patterson, N. Bhowmik, M. Johnson, J. Teal. 2003. Comparison of the long-term risks of removal and in situ management of contaminated sediments in the Fox River. Soil \& Sediment Contamination, 12 (3) (2003), pp. 325-344

[4] J.L. Go, D.J. Lampert, J.A. Stegemann, D.D. Reible. 2009. Predicting contaminant fate and transport in sediment caps: mathematical modeling approaches. Applied Geochemistry., 24 (7) (2009), pp. 1347-1353.

[5] G.J Thoma, D.D. Reible, K.T. Valsaraj, L.J. Thibodeaux. 1993. Efficiency of capping contaminated sediments in situ. 2 . Mathematics of diffusion adsorption in the capping layer. Environmental Science \& Technology, 27 (12) (1993), pp. 2412-2419.

[6] H. Choi, , S. Agarwal, S.R. Al-Abed. 2009. Adsorption and simultaneous dechlorination of PCBs by GAC impregnated with ZVI/Pd bimetallic particles: mechanistic aspects and reactive capping barrier concept. Environmental Science \& Technology, 43 (2) (2009), pp. 488-493

[7] J.R.Zimmerman, U. Ghosh, R.N. Millward, T.S. Bridges, R.G. Luthy. Addition of carbon sorbents to reduce PCB and PAH bioavailability in marine sediments: physicochemical tests. Environmental Science \& Technology, 38 (20) (2004), pp. $5458-5464$

[8] V.Krumins, J.-W. Park, E.-K. Son, L.A. Rodenburg, L.J. Kerkhof, M.M. Häggblom, D.E. Fennell. 2009. PCB dechlorination enhancement in Anacostia River sediment microcosms. Water Research, 43 (18) (2009), pp. 4549-4558

[9] G.V. Lowry, K.M. Johnson. 2004. Congener specific PCB dechlorination by microscale and nanoscale zero-valent iron in a methanol/water solution. Environmental Science \& Technology, 38 (19) (2004), pp. 5208-5216

[10] S. Hyun, C.T. Jafvert, L.S. Lee, P.S.C. Rao. 2006. Laboratory studies to characterize the efficacy of sand capping a coal tar-contaminated sediment. Chemosphere, 63 (10) (2006),pp. $1621-1631$

[11] P.H. Jacobs, U. Förstner. 1999. Concept of subaqueous capping of contaminated sediments with active barrier systems (ABS) using natural and modified zeolites. Water Research, 33 (9) (1999), pp. 2083-2087.

[12] K.M. McDonough, P. Murphy, J. Olsta, Y.W. Zhu, D. Reible, G.V. Lowry. Development and placement of a sorbent-amended thin layer sediment cap in the Anacostia River. Soil \& Sediment Contamination, 16 (3) (2007), pp. 313-322.

[13] P. Murphy, A. Marquette, D. Reible, G.V. Lowry. 2006. Predicting the performance of activated carbon-, coke-, and soil-amended thin layer sediment caps. Journal of Environmental Engineering - ASCE, 132 (7) (2006), pp. 787-794.

[14] D.D. Reible, D. Lampert, D.W. Constant, R.D.Mutch, Y.Zhu. 2007. Active capping demonstration in the Anacostia River, Washington, DC. Remediation, 17 (1) (2007), pp. 39-53.

[15] AquaBlok, Ltd., http://www.aquablokinfo.com/

[16] J.H. Hull, J.M. Jersak, and C.A. Kasper. 1999. In-Situ Capping of Contaminated Sediments: Comparing the Relative Effectiveness of Sand Versus Clay Mineral-Based Sediment Caps. Unpublished.

[17] J.H. Hull, J.M. Jersak, and H.F. Crowell. 2000. 'Biofriendly' Remediation of Impacted Wetlands. In: JR Means and RE Hitchee (eds') Wetlands and Remediation International Conference Proceedings, pp 229-236.

[18] U.S. EPA Releases SITE Evaluation Report - accessed from http://nep is.epa.gov/Exe/ZyPURL.cgi?Dockey=P10030OW

[19] Demonstration of the AquaBlok Sediment Capping Technology.http://www.epa.gov/region1/superfund/sites/nya nza/466646.pdf

[20] M.R. Palermo, R.A. Shafer, J.M. Brannon, C.L. Truitt, M.E. Zappi, J.G. Skogerboe, S.A. Adamec, T.C. Sturgis, R. Wade, D. Gunnison, and T.E. Myers. 1989. "Evaluation of Dredged Material Disposal Alternatives for US Navy Homeport at Everett, Washington," Technical Report, EL-89-1, US Army Engineer Waterways Experiment Station, Vicksburg, MS

[21] M.S. Dortch, L.Z. Hales, J.V. Letter, and W.H. McAnally. 1990. "Methods of Determining the Long Term Fate of Dredged Material for Aquatic Disposal Sites," Technical Report, D-90-1, U.S. Army Engineer Waterways Experiment Station, Vicksburg, MS. 
[22] Hugo Coops and Gerard van der Velde 1995. Seed dispersal, germination and seedling growth of six helophyte species in relation to water-level zonation. Freshwater Biology. Volume 34 Issue 1. pp 1-13

[23] Kellogg, Chev H. Scott D. Bridgham† and Stacey A. Leicht 2003. Effects of water level, shade and time on germination and growth of freshwater marsh plants along a simulated successional gradien Journal of Ecology Volume 91 pp 274.

[24] American Society for Testing and Materials (ASTM) International. 2007. ASTM D2974-00 Standard Test Methods for Moisture, Ash, and Organic Matter of Peat and Other Organic Soils.

[25] American Society for Testing and Materials (ASTM) International. 2007. ASTM D422 - 63 Standard Test Method for Particle-Size Analy sis of Soils

[26] United States Environmental Protection Agency 2005. Fourth edition. "Test Methods for Evaluating Solid Waste, Physical/Chemical Methods", SW-846.

[27] D. Persaud, Jaagumagi, R., and A. Hayton, 1992. Guidelines for the Protectionand Management of Aquatic Sediment
Quality in Ontario. Ontario Ministry of the Environment, Queen's Printer for Ontario.

[28] Ilya Raskin, PBA Nanda Kumar, Slavik Dushenkov, David E Salt. 1994. Bioconcentration of heavymetals by plants. Current Opinion in Biotechnology. Volume 5, Issue 3, pp. 285-290

[29] T Sawidis, M K Chettri, G A Zachariadis, J A Stratis. 1995. Heavy metals in aquatic plants and sediments from water systems in Macedonia, Greece. Ecotoxicology and Environmental Safety. Volume: 32, Issue: 1, pp. 73-80

[30] James P. Bennett, Esteban Chiriboga, John Coleman, Donald M. Waller. 2000. Heavy metals in wild rice from northern Wisconsin. Science of The Total Environment, Volume 246, Issues 2-3,pp. 261-269

[31] R. Reboreda, I. Caçador. 2007. Copper, zinc and lead speciation in salt marsh sediments colonized by Halimione portulacoides and Spartina maritime. Chemosphere, 69-pp. 1655-166. 